\title{
DEVELOPMENT OF THE IMAGE OF REZEKNE CITY
}

\author{
Robel Ogbazghi \\ Worms University of Applied Science, Germany, \\ e-mail: tour2954@hs-worms.de, phone: +4917631631693
}

\begin{abstract}
The research analyzes the development of the image of Rezekne city (Latvia). Attractiveness of a city is described by its image. Three main target groups which are interested in city's attractiveness are: dwellers, tourists, and business people. The attitude of these target groups were researched in the previous studies by several researchers. It is important to review the negative and positive aspects presented in this research study to minimize the negative elements and highlight the positive or attractive elements. The nature of Rezekne as a potential tourist destination, mainly in the scope of its history and attractions, is an important issue which is discussed in this paper.

The research was qualitative and exploratory, consisting of a literature review followed by an empirical investigation using interviews with tourism experts located in the city of Rezekne. The aim of the research study is to investigate tourism specialists' views on the opportunities for increasing the attractiveness of Rezekne city for tourists.
\end{abstract}

Keywords: attractiveness, image development, image of city, tourists, tourist destination

JEL code: M390, L830

\section{Introduction}

Rezekne is the $7^{\text {th }}$ largest city in Latvia. It is located at the cross of two strategically important transportation trunk roads and railway (RigaMoscow and St. Petersburg-Warsaw), which creates good preconditions for successful development of the city. It has become a border city between the EU, NATO, and the Eastern states. Rezekne is located $242 \mathrm{~km}$ from the state capital Riga, $685 \mathrm{~km}$ from Moscow, $450 \mathrm{~km}$ from St. Petersburg, and $860 \mathrm{~km}$ from Warsaw.

Furthermore, the city provides several tourism offers like picturesque nature, historical and cultural monuments, and more. In addition, the city continues to develop activities with aim to increase incomes from tourists. Image of city and city's marketing increasingly become important issues for cities to ensure and maintain their attractiveness to tourists.

Improvements of infrastructure, several famous events like the 'Half Marathon', 'Latgale Pottery Days', 'Week of Latgalian Films' and 'Latgalian Gold Autumn's Sounds' festival, or cultural and historical objects like the Concert Hall 'GORS', which is known as the best concert hall in the Baltic area in terms of acoustic quality, are the reasons of the increasing number of tourists in Rezekne. 
The attractiveness of Rezekne city has been investigated by several researchers: Ezmale S., Litavniece L., Silinevica I., Znotina D., Silicka I., Dembovska I. They have researched the attitude of the main target groups (city dwellers, business people, tourists) to attractiveness of Rezekne.

Unlike the previous studies, this research has explored the tourism specialists' views on the opportunities to increase the city's attractiveness in the view of tourists. The aim of this research study is to investigate the opportunities to increase the attractiveness of Rezekne city for tourists from the tourism specialists' point of view.

Hypothesis of the research: Rezekne city interesting for tourists with its cultural, historical, or relax opportunities. The methods used in this research study are as follows: the expert interview method, logical constructive methods, content analysis.

\section{Analysis of inbound tourism in Rezekne city}

According to Latgales statistika (Tab.1), the number of tourists in Rezekne increases year by year. In 2013 , there were 12,277 guests who used tourist accommodation services, in 2014 - 14,816 guests, and in 2015 - around 16,275.

Table 1

Number of tourists in Rezekne in 2013-2015

(Source: Latgales statistika, 2016)

\begin{tabular}{|c|c|c|c|c|c|c|c|c|}
\hline Year & $\begin{array}{c}\text { Tourist } \\
\text { accommo- } \\
\text { dation } \\
\text { services }\end{array}$ & Craftsman & $\begin{array}{c}\text { Museums } \\
\text { work-shops } \\
\text { Exhibition }\end{array}$ & $\begin{array}{c}\text { Cultural, } \\
\text { historical, } \\
\text { and sacral } \\
\text { objects }\end{array}$ & $\begin{array}{c}\text { Farms } \\
\text { visita- } \\
\text { tions }\end{array}$ & $\begin{array}{c}\text { Rec- } \\
\text { reation } \\
\text { firms }\end{array}$ & $\begin{array}{c}\text { Natural } \\
\text { objects }\end{array}$ & Total \\
\hline 2013 & 12277 & 1748 & 15846 & 760 & 45013 & - & 2789 & 78433 \\
\hline 2014 & 14816 & 3434 & 19623 & 823 & 56565 & - & 3213 & 78851 \\
\hline 2015 & 16275 & 3455 & 21213 & 836 & 58721 & 400 & 3316 & 104206 \\
\hline
\end{tabular}

As well, annual growth in the number of participants of such events like 'Craftsman workshops', 'Museums \& Exhibitions', 'Cultural, historical and sacral objects', 'Farm visitations', and 'Natural objects' was estimated. In 2015 , the total number of tourists had increased by 25,355 visitors, compared with 2014. 


\section{Research results}

\section{Methodology}

The aim of this empirical study is to discover the attractiveness of Rezekne City for tourists and to find out which are the opportunities the city provides to meet the needs of tourists from the tourism specialists' viewpoint.

For the research of this topic Express Interviews method was selected. The following factors have served as the main reasons of this selection: efficiency, high reliability, and quick obtainment of good results. Bogner, Littig, and Menz (2009) explain the advantages the Express Interviews methodology in this way: 'talking to experts in the exploratory phase of a project is a more efficient and concentrated method of gathering data than, for instance, participatory observation or systematic quantitative surveys. Conducting expert interviews can serve to shorten time-consuming data gathering processes, particularly if the experts are seen as "crystallization points" for practical insider knowledge and are interviewed as surrogates for a wider circle of players. Expert interviews also lend themselves to those kinds of situations in which it might prove difficult or impossible to gain access to a particular social field'.

As experts in the field of tourism marketing the following specialists were interviewed, see Tab.2.

Table 2

Experts in the field of tourism marketing (source: author's data)

\begin{tabular}{|l|c|c|}
\hline \multicolumn{1}{|c|}{$\begin{array}{c}\text { Name of } \\
\text { expert }\end{array}$} & Current position & Experience in tourism industry \\
\hline R. Liepina & $\begin{array}{c}\text { Professor, owner of guest } \\
\text { house }\end{array}$ & $\begin{array}{c}\text { Owner of guest house „Sidari”, Latgale } \\
\text { region (15 years) }\end{array}$ \\
\hline I. Silineviča & $\begin{array}{c}\text { Professor in Regional Econo- } \\
\text { mics in Rezekne Academy of } \\
\text { Technology (RTA) }\end{array}$ & $\begin{array}{c}\text { Tourism guide (6 years) } \\
\text { Manager of regional tourism projects (3) } \\
\text { Author of textbook „, Tourism Analysis” }\end{array}$ \\
\hline I. Balčūne & $\begin{array}{c}\text { Manager of Luznava Manor in } \\
\text { Rezekne Municipality }\end{array}$ & $\begin{array}{c}\text { Developer of new tourist products } \\
\text { (1 year) }\end{array}$ \\
\hline V. Deksne & Owner of a guest house & Owner of a guest house (8 years) \\
\hline I. Dembovska & Lecturer in RTA & $\begin{array}{c}\text { Experience in tourism industry } \\
\text { (15 years) }\end{array}$ \\
\hline I. Silicka & Lecturer in RTA & $\begin{array}{c}\text { Experience in tourism industry } \\
\text { (20 years) }\end{array}$ \\
\hline E. Pastare & $\begin{array}{c}\text { Tourism information } \\
\text { consultant at Rezekne } \\
\text { Tourism Development Centre }\end{array}$ & $\begin{array}{c}\text { Previously - a consultant at Klein Ltd in } \\
\text { Riga, Experience working with foreign } \\
\text { tourists. (3 years) }\end{array}$ \\
\hline I. Zelča & $\begin{array}{c}\text { Consultant at Tourism Infor- } \\
\text { mation Centre in Rezekne }\end{array}$ & \begin{tabular}{c} 
Tourism consultant (9 years) \\
\hline
\end{tabular} \\
\hline
\end{tabular}


Several questions were included in the survey. They were related to the tourism attractiveness of Rezekne city, and to the tourists' satisfaction with transport prices, and their satisfaction with tourism objects. The interviewees were asked to formulate recommendations for increasing the attractiveness of Rezekne for tourism.

\section{Results of the express interviews}

\section{Tourist attractiveness of Rezekne city}

The statement 'GORS is the brand of Rezekne City' was included in the survey because of its popularity far outside of Rezekne city. Brand of the concert hall GORS has been developed in cooperation with the brand development company MATKA and inhabitants of Latgale and is considered as a symbolic location expressing Latgale's immense will to live. In the formulated statement, all respondents (100\%) have confirmed that GORS is the brand/trademark of Rezekne city.

The statement 'ZEIMULS is very attractive for tourists' was included in the survey because of the breath-taking view to the castle hill and the historical city centre from the towers of the building. Moreover, it is regarded as the largest building under a green roof in the Baltic region and had been nominated for the "Latvian Architecture Award 2012". It is one of the most original buildings in Latvia and it is recognised as the tourism object. $62 \%$ of the respondents have agreed in the opinion that ZEIMULS represents an attractive object for tourists. However, $25 \%$ of respondents have somewhat agreed and $13 \%$ - have disagreed with this statement.

The statement 'Lagale's culture and history museum' is the main tourism object which discovers Latgalian identity' was included in the survey because visitors can explore thoroughly the history of the city, enjoy a variety of art exhibitions and join creative workshops.

$50 \%$ of the respondents have strongly agreed and $25 \%$ agreed, and confirmed that 'Latgale's culture and history museum' was the main tourism object discovering Latgalian identity. The other $25 \%$ somewhat agreed with the statement.

The statement 'Rezekne is interesting only for tourists who are interested in history and culture' was included in the questionnaire because it would help to find out if Rezekne had attractive places to offer for tourists without special interest in history and culture. $75 \%$ of the experts have strongly agreed, agreed, or somewhat agreed, and are of the opinion that the main focus of the city is based on history and culture tourism. But $25 \%$ of the respondents disagreed with this statement. 
The statement 'The monument "United for Latvia" (Latgale's Mara) is the most recognizable symbol of Rezekne' was included in the survey because it is the monument devoted to the participation of Latvians in war for independence in 1920 and is therefore an extremely important symbol of Rezekne city and very popular among tourists. It represents the efforts the nation has undertaken to rebuild and protect their country. According to the survey of experts, the monument 'United for Latvia' represents the most recognizable symbol of the city: $80 \%$ of the respondents have strongly agreed and $20 \%$ - agreed with the statement.

The statement 'The new Engineering Faculty building of Rezekne Academy of Technologies is a symbol for the way of innovative thinking of Rezekne' was included in the questionnaire because it is one of the most contemporary buildings in the city. It reflects the progress and development of the city and in the whole region. At this point, all the experts $(100 \%)$ have strongly agreed or agreed with the statement and had the opinion that the modern engineering faculty building demonstrates the innovation and progress of the city.

The statement 'The Castle Hill is the most remarkable and most visited place in Rezekne' was involved in the survey because it represents the oldest historical monument and is therefore one of the places most visited by tourists. The evaluation of this statement shows that $62.5 \%$ of the respondents strongly agree or agree and are fully convinced that the Castle Hill is actually one of the most visited attractions in the city; $37.5 \%$ of the experts have somewhat agreed with this statement.

The statement 'Means of transport for tourists are available $24 h$ ' was involved in the questionnaire because accessibility and the number of transport options have a great importance for tourists. $62,5 \%$ of the respondents have strongly disagreed or disagreed, and only $37.5 \%$ of the respondents have somewhat agreed with this statement. According to the experts, the transportation links within the city are rather skinny and upgradeable. During the day, one can get relatively well around the town, but it becomes difficult in the late evening.

The statement 'In the restaurants you will mainly find traditional Latgalian food' was included in the questionnaire because traditional dishes are part of the culture. Tourists are not interested just seeing culture, but also tasting it. However, there are also tourists who prefer to eat food familiar to them. Therefore it is important to know, if tourists can find both in the restaurants. At this point, $67.5 \%$ of the experts have disagreed answering that a person could find more than just traditional Latvian food in the restaurants. Aside from that, there are some international food stalls such as 'Ausmenja Kebab' and 'La Pizza', or a traditional Chinese restaurant. In addition, visitor can find popular 
international dishes on the menu in any restaurant. $20 \%$ of the respondents have somewhat agreed and only $12.5 \%$ - agreed with this statement.

The statement 'Rezekne Academy of Technologies has a remarkable role in preparing specialists for the tourism industry' was included in the survey because tourism specialists are needed for the development of the tourism industry in Rezekne. There are study programme with tourism management specialization in Rezekne Academy of Technologies. 62.5\% of the experts have strongly agreed/agreed and 37.5\% - somewhat agreed with this statement and are absolutely confident that 'Rezekne Academy of Technologies' plays a quite important and productive role in terms of development of tourism experts.

The statement 'The quality of the hotel infrastructure in Rezekne meets the European standards and expectations of tourists' was included in the survey because tourists make great emphasis on comfort and hygiene in hotels. Judged by the experts, the quality of the hotels and accommodations in the city is satisfactory and represents a relatively good price-performance ratio. 50\% of the respondents have somewhat agreed and $37.5 \%$ - agreed with this statement. Only $12.5 \%$ of the experts have disagreed.

The statement 'The quality of service in hotels meets the European standards' was included in the questionnaire because not only hygiene and comfort are important for tourists. In order to make customers not just satisfied but as well inspired for a return visit, a good service is necessary. Hence, the quality of service in the hotels and lodging meets the European standards according to the experts. $87.5 \%$ of the experts have agreed with this statement and only $12.5 \%$ of them have disagreed.

The statement 'The quality of the restaurant infrastructure meets the European standards' was involved in the survey because not only the quality of food is important for tourists but also the ambience and the atmosphere have a major impact on the customers satisfaction. $37.5 \%$ of the respondents have agreed and another $37.5 \%$ - somewhat agreed with this statement. However, $25 \%$ of the experts have disagreed in this case.

The statement 'The quality of service in restaurants meets the European standards' was included in the questionnaire because the service quality (friendliness/speed) has an extremely important role in restaurants. Even if the ambience is excellent, a bad service can be fatal for the business. On this issue, $37.5 \%$ of the experts have agreed and $25 \%$ somewhat agreed with this statement. However, $37.5 \%$ of the respondents have disagreed and are of the opinion that the quality of service in restaurants doesn't meet the European standards. 
The statement 'There is good access to Rezekne by car, and by train' was included in the survey because not only the transportation options within the city are important to tourists, but as well the access to the city from outside. If the place is difficult to reach, city can lose potential tourists.

Most of the respondents (87.5\%) are convinced that accessibility of the city from outside is relatively satisfactory, only $12.5 \%$ of the respondents have disagreed with this statement.

The statement 'Rezekne has a good location from the geographical aspect' was included in the questionnaire because the geographical location of a place has a great importance for tourism as well as for business (companies). If the neighbouring towns or regions are more accessible, the possibility to attract visitors or companies is higher.

According to the experts (87.5\%), the city has a very good geographical location. $12.5 \%$ of the experts have somewhat agreed with this statement. Rezekne is situated in about $250 \mathrm{~km}$ to the east from Riga and around $63 \mathrm{~km}$ to the west from the Latvian-Russian border, at the intersection of the roads and railways of Moscow-Riga and Warsaw-Saint Petersburg transport routes.

\section{Price-performance ratio of transportation}

The statement 'Please evaluate the price-performance ratio of the following transport opportunities' was included in the survey because the number, as well as prices, are extremely important for tourists.

$50 \%$ of all respondents have the opinion that the price-performance ratio of public buses is good, $37.5 \%$ of respondents have answered that it is moderate. Only $12.5 \%$ consider that the price-performance ratio of buses is excellent.

In the case of taxis, $62.5 \%$ of the experts believe that the priceperformance ratio is good, and $37.5 \%$ of them have noted that it is moderate.

Concerning the car rental, $62.5 \%$ of respondents have the opinion that the price-performance ratio is bad and $37.5 \%$ says it is moderate.

\section{Satisfaction of tourists with tourism objects}

The question 'To what extent does Rezekne meet the needs of tourists?' was involved in the questionnaire because more tourism offers the city can provide, more needs of tourists can be met. $62.5 \%$ of the experts have the opinion that the environment, in general, in Rezekne is very good or even 
excellent for tourists, $37.5 \%$ of experts believe the natural environment provided by the city is good.

Regarding 'the historical sights', $62.5 \%$ of the respondents have mentioned that Rezekne offers excellent/very good opportunities to visit historical places. Another $37.5 \%$ have noted it is good, but not excellent.

On the issue 'nightlife', $75 \%$ of the experts consider that the opportunities offered are average. $12.5 \%$ of respondents consider the nightlife opportunities as poor, and only $12.5 \%$ agree they are good.

Regarding 'shopping', $50 \%$ of the experts have the opinion that the opportunities are poor. The other $50 \%$ believe they are average.

$62.5 \%$ of the respondents believe that tourism information is very good and 25\% have even mentioned it is excellent. Furthermore, 12.5\% consider that the tourism information in Rezekne is good.

Regarding the issue 'beach', $37.5 \%$ of the experts have valuated it as poor and $25 \%$ have told it is average. Only $25 \%$ consider it is good.

\section{Brand of Rezekne City}

A query 'Please, state the brand of Rezekne City' was included in the survey because it was interesting to find out what the particular experts thought of the brand of the city. All of the respondents, 100\%, have agreed that 'GORS' is the image of Rezekne.

\section{Recommendations for tourism development in Rezekne}

A request 'Please, name your suggestions for development of tourism in Rezekne!' was included in the questionnaire because it would help to find out opportunities for tourism development in Rezekne by evaluating the ideas and solutions of tourism experts. The developed proposals vary depending on the experts' views.

- Prof. Liepina (owner of the guest house) have noted that the development of low-price hostels and holding of different festivals as 'Latgale Folk Dance', 'Latgale Schlager Days', or 'Latgale Festival of Musicians' would be very important for tourism development in Rezekne.

- Prof. Silineviča is convinced that development of the tourism interest education (hobby groups) in every school (primary and secondary) of Latgale region would provide a good development opportunity for tourism. The aim of this informal education would be to raise children's interest about tourism opportunities in the native region from the early age.

- Mrs. Balcune, the manager of Luznava Manor in Rezekne 
Municipality, have concluded that an improvement of public transport and car rental is necessary for development of tourism attractiveness of Rezekne city.

- Mrs. Deksne, owner of the guest house, is convinced that development of medical tourism would be helpful to increase tourism revenues in Rezekne.

- Lect. Dembovska considers that creation of a new attractive tourism products (e.g. a new Spa hotel) would be a reasonable solution.

- The specialist of the Tourism Development Centre suggests to pay attention to development of the active tourism segment to attract more families with children and to make the city more alluring not only for admirers of culture and history, but also for fans of active recreation.

\section{Conclusions and suggestions}

Overall, the tourism offer of Rezekne city proves to be consistently positive, even if there are undeniable weaknesses. Despite the slowly increasing number of visitors, it is possible to speak about a very modest tourists' track record due to the existing versatile tourism infrastructure, recently achieved success in marketing, and promising potential.

The main potential of the city is its culture, history, and still untouched nature offering relaxation, nature experience, and enjoyment for the tourists.

The biggest challenge on the part of tourism stakeholders is to promote tourism, while obtaining its most valuable asset, the unique landscape, and natural heritage. Accordingly, establishment of a nature park and the classification as a world heritage can be considered as a key success factor for the sustainable tourism development in Rezekne.

The research has also shown that, in terms of marketing, not all of the tourism potential has been exploited. There is a lack of a comprehensive target group and theme-oriented marketing with clear strategies at the national and international level. Rezekne impresses with its diversity in a small location and needs to be positioned as an attractive destination on the global tourism market.

To obtain the tourists' appreciation, for example, an implementation of the ideas and solutions of the experts is needed. Though, it is possible only if the local, regional, and national stakeholders follow a clear strategy with exactly defined objectives and measures. 


\section{References}

1. BOGNER, A., LITTIG, B., MENZ, W. (2009). Introduction: Expert interviews - An introduction to a new methodological debate. Retrieved April 2, 2016 from https://www.researchgate.net/file.PostFileLoader.html?id...assetKey.

2. DEMBOVSKA, I., SILICKA, I. (2015). Development of professional competencies of hospitality industry specialists within the framework of acquisition of educational module „Organization of hospitality services”. Latgale national Economy research. Journal of Social Sciences. Research papers, p.164-178.

3. EZMALE, S. (2012). Economic development, employment and welfare of Rezekne population in the improvement of city attractiveness. Latgale national Economy research. Journal of Social Sciences. Research papers, p.7-44.

4. Latgales statistika (2012-2013).Retrieved Mart 02, 2016 from www.visitdaugavpils.lv/sites/.../latgales_statistika_2012-2013_1.docx

5. Latgales statistika (2014). Retrieved Mart 02, 2016 from www.visitdaugavpils.lv/sites/default/files/latgale_statistika_2014.docx

6. Latgales statistika (2015). Retrieved Mart 02, 2016 from www.aglona.lv/wpcontent/uploads/2016/.../Latgales-statistika-2015.pdf

7. LITAVNIECE, L. (2012). Cultural, sports and recreational services in evaluating city attractiveness: example of Ludza town. Latgale national Economy research. Journal of Social Sciences. Research papers, p.117-143.

8. LITAVNIECE, L., ZNOTINA, D. (2015). External business environment problems and opportunities in Rezekne city. Latgale national Economy research. Journal of Social Sciences. Research papers, p.107-119.

9. Rezekne geographical layout. Reviewed 20. Apri, 2016. from: http://www.rezekne.lv/en/about-rezekne/geographical-layout/

10. SILINEVIČA, I. (2010). The attractiveness of cities in the frame of regional development. Journal of Social Sciences: Human resources Klaipeda University. Social Science faculty - the main factor of regional development, No.3, p.74-80.

11. SILINEVIČA, I. (2012). Research on attractiveness aspects of Dagda town as a centre of Dagda county from the perspective of its inhabitants. Latgale national Economy research. Journal of Social Sciences. Research papers, p.168.-190.

12. VISKERS, E. (2012). Cultural, sports and recreational services as factors influencing city attractiveness from the point of view of Kraslava town inhabitants. Latgale national Economy research. Journal of Social Sciences. Research papers, p.191-211. 


\title{
RĒZEKNES PILSĒTAS TĒLA ATTİSTĪBA \\ Robel Ogbazghi
}

\author{
Vormsas Lietiškso zinātṇu universitāte
}

\section{Kopsavilkums}

Iepriekšējie pētījumi par Rēzeknes pilsētas pievilcību aptvēra trīs galvenās mērksa grupas: pilsētas iedzīvotājus, tūristus un cilvēkus, kas nodarbojas ar uzñēmējdarbībai.

Šì pētījuma mērḳis ir izzināt tūrisma speciālistu viedokḷus par iespējām palielināt Rēzeknes pilsētas pievilcību tūristu mērksa grupai.

Pētījumā izmantotās metodes: ekspertu intervija, loǵiski konstruktīvā metode un kontentanalīze,

Rēzeknes pilsēta tūristiem visnotal atraktīva. Neskatoties uz to, ka apmeklētāju skaits pieaug lēni, daudzveidīga tūrisma infrastruktūras izaugsme veido daudzsološu tūrisma galamērksa potenciālu. Galvenās tūrisma pievilcības pilsētā veido kultūras, vēstures un dabas objekti, kas piedāvā atpūtas, un dabas baudījumu iespējas. Pats lielākais izaicinājums no tūrismā ieinteresētajām personām ir pievienotās vērtības radīšana, izmantojot kultūrvēsturisko mantojumu, unikālo ainavu un dabas mantojumu, ko var uzskatīt par noteicošo veiksmes faktoru ilgtspējīgai tūrisma attīstībai Rēzeknē.

Atslēgas vārdi: pievilcība, tēla veidošana, pilsētas tēls, tūristi, tūristu galamērḳis. 